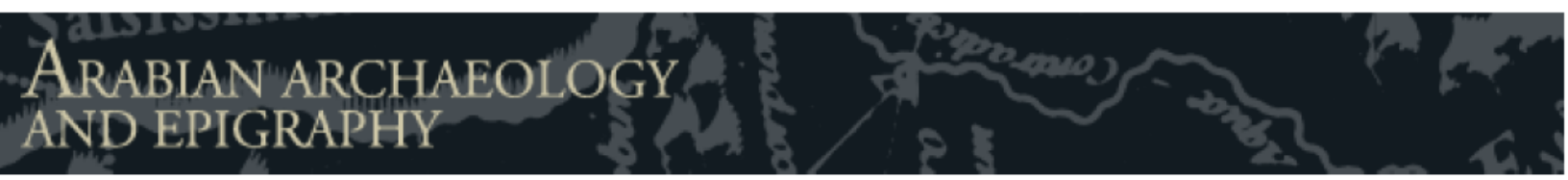

\title{
The PalaeoEnvironments and ARchaeological Landscapes \\ (PEARL) project: recent findings from Neolithic sites in Northern Oman
}

\begin{tabular}{|c|c|}
\hline Journal: & Arabian Archaeology and Epigraphy \\
\hline Manuscript ID & Draft \\
\hline Wiley - Manuscript type: & Original Article \\
\hline $\begin{array}{r}\text { Date Submitted by the } \\
\text { Author: }\end{array}$ & $n / a$ \\
\hline Complete List of Authors: & $\begin{array}{l}\text { Parton, Ash; Oxford Brookes University, Human Origins and } \\
\text { Palaeoenvironments; Oxford University, Mansfield College } \\
\text { Bretzke, Knut; University of Tübingen, Early Prehistory and Quaternary } \\
\text { Ecology; }\end{array}$ \\
\hline Keywords: & Neolithic, Holocene, Oman, Palaeoenvironments, Excavation \\
\hline Abstract: & $\begin{array}{l}\text { The PalaeoEnvironments and ARchaeological Landscapes (PEARL) } \\
\text { research project is a joint German-British project with the principal } \\
\text { objective of developing a framework of past human occupation and } \\
\text { landscape change in Southeastern Arabia. Fieldwork during } 2018 \text { and } \\
2019 \text { involved the systematic survey and excavation of sites in the } \\
\text { Rustaq and Ibri regions of Northern Oman, with the aim of establishing } \\
\text { the nature and timing of human occupation and landscape change during } \\
\text { the Early Holocene period (ca. 10-7,000 years BP). Further to the } \\
\text { findings previously reported, results from recent excavations of the site } \\
\text { Hayy al-Sarh in Rustaq revealed the presence of animal remains, stone } \\
\text { and shell beads and stone structures, indicating a large Neolithic } \\
\text { settlement with burial areas. In addition, preliminary excavations at a } \\
\text { rock shelter site near Ibri have revealed stratified archaeological } \\
\text { remains, including a Fasad type assemblage. Future fieldwork will further } \\
\text { develop archaeological and palaeoenvironmental records to help build a } \\
\text { framework for studying cultural and natural developments in northern } \\
\text { Oman. }\end{array}$ \\
\hline
\end{tabular}


1 The PalaeoEnvironments and ARchaeological Landscapes (PEARL)

2 project: recent findings from Neolithic sites in Northern Oman

\section{Abstract}

5 The PalaeoEnvironments and ARchaeological Landscapes (PEARL) research project

6 is a joint German-British project with the principal objective of developing a

7 framework of past human occupation and landscape change in Southeastern Arabia.

8 Fieldwork during 2018 and 2019 involved the systematic survey and excavation of

9 sites in the Rustaq and Ibri regions of Northern Oman, with the aim of establishing the

10 nature and timing of human occupation and landscape change during the Early

11 Holocene period (ca. 10-7,000 years BP). Further to the findings previously reported,

12 results from recent excavations of the site Hayy al-Sarh in Rustaq revealed the

13 presence of animal remains, stone and shell beads and stone structures, indicating a

14 large Neolithic settlement with burial areas. In addition, preliminary excavations at a

15 rock shelter site near Ibri have revealed stratified archaeological remains, including a

16 Fasad type assemblage. Future fieldwork will further develop archaeological and

17 palaeoenvironmental records to help build a framework for studying cultural and

18 natural developments in northern Oman.

20 Key words: Neolithic, Holocene, Oman, palaeoenvironments, excavation 


\section{Introduction}

The PalaeoEnvironments and ARchaeological Landscapes (PEARL) research project is a joint German-British project with the principal objective of establishing a framework for studying prehistoric human occupation history and its relationship to paleoenvironmental change in southern Arabia. This objective is underpinned by the development of securely dated archaeological and palaeoenvironmental records, which together will provide important information regarding the relationship between climatic/environmental change and human prehistory in arid zones. While the scope of the PEARL project geographically includes the entirety of southern Arabia (U.A.E, Oman), and chronologically includes records from both the Pleistocene period (> $12,000 \mathrm{BP}$ ) and the Early to Mid-Holocene (ca. 12,000 to 4,000 BP), we focus in this paper on the latter period and records from Northern Oman. Here the sites of Hayy alSarh - a stratified Neolithic site near the town of Rustaq and IB19 - a rock shelter sequence near the town of Ibri, form the basis of the PEARL project's current research on the Neolithic in the region. While the project is in it's early stages and as such, final conclusions from these records remain untested, we believe that the information gained thus far can be used to explore potential implications within a wider context in inter-regional palaeoenvironmental and archaeological investigations.

\section{Project Background}

The Early Holocene/Neolithic period is generally well understood with respect to chronology and material culture in comparison with other archaeological periods in Southeast (SE) Arabia (Charpentier 2008, Uerpmann et al. 2013, Crassard and 
47 Drechsler 2013). Similarly, the palaeoenvironmental record for the region is also well developed, and indicates a widespread increase in rainfall from ca. $10 \mathrm{ka}$ leading to an increase in freshwater availability and subsequent rise in terrestrial net primary productivity (e.g. Parker et al., 2006; Fleitmann et al., 2007; Lézine et al., 2010;

Preston et al., 2015). While there is broad agreement that improved (wetter) climatic conditions would likely have facilitated inter-regional biogeographic connectivity during the Early Holocene, a number of key issues remain unresolved. In particular, the Palaeolithic/Neolithic transition and associated shift in subsistence strategies is poorly understood, as are the relationships between coastal and inland sites, and the responses of communities to climatic variability (Crassard and Drechsler, 2013).

These gaps in our knowledge are inherently linked to scalar issues of spatio-temporal resolution. Principally, the spatial distribution of both archaeological and palaeoenvironmental sites across the region is intermittent and insufficient for resolving questions of landscape change/usage and subsistence strategies. In particular, data from stratified inland sites are distinctly underrepresented in comparison with evidence from coastal regions, where the vast majority of the region's excavated sites are located (Mery and Charpentier, 2013). Existing data from inland sites in SE Arabia (e.g. Uerpmann et al., 2000; 2013; 2018; Kallweit et al., 2005; Lemée et al., 2013; Rose et al., 2014) suggest repeated phases of occupation of the interior between the $9^{\text {th }}$ and $5^{\text {th }}$ millennium $\mathrm{BC}$, interspersed with phases that lack evidence for human occupation (Drechsler, 2010; Uerpmann et al., 2013). The absence of evidence, however, should not be taken as evidence for absence; while climatically mediated landscape changes may have played an important role in demographic variability during the Early Holocene period, at present, large spatial gaps in our understanding of site distribution patterns remain. A key objective of the 
72 PEARL project, therefore, is to address this issue through the identification and investigation of sites within a range of inland geomorphic settings, which may then be placed within a local-regional framework of landscape and resource change.

In order to develop this framework, a greater range of palaeoenvironmental sequences than currently exist, are required from regions such as Northern Oman. While the speleothem record from Hoti Cave provides an excellent master record of Indian Ocean Summer Monsoon (IOSM) variability (e.g. Fleitmann et al., 2007), there is currently a paucity of environmental data that provide information about the way in which the landscape of the region has responded to climatic changes during the Holocene. The geomorphic setting of SE Arabia is remarkably varied, and during the Early Holocene would have comprised a mosaic of habitats and ecotones featuring mountainous regions, well-watered alluvial plains, savannah grasslands, stable dune fields and productive coasts. Depending upon the spatial and temporal variability of seasonal rainfall, these regions would have periodically been hydrologically interlinked, affording greater biogeographic connectivity and resource availability. In the present day, SE Arabia is characterised by steep rainfall gradients across a range of landscape settings: Daqeeq in the Northern Oman Mountains is in receipt of 175.4 $\mathrm{mm}$ mean annual rainfall, while desert regions of the UAE receive $74.9 \mathrm{~mm}$ (Kwarteng et al., 2009; Sherif et al., 2014). Such climatic and geomorphic variability has led to a great diversity of biogeographical distributions and centres of endemism, with the Western Hajar Mountains being one of the richest floristic regions within Arabia (Patzelt, 2014). The region is currently home to 24 endemic plants species including evergreen woodland communities indicative of a former continuous belt of xeromorphic woodlands (Patzelt, 2014), and three species of freshwater fish endemic 
97 favourable environmental conditions may have facilitated occupation continuity in some regions of SE Arabia during the Holocene. Consequently, detailed records of geomorphic and ecological variability from a range of landscape settings are critical for our understanding of changes in past resource availability. To achieve this, a second key objective of PEARL is to adopt a 'source-to-sink' approach when conducting palaeoenvironmental investigations, whereby evidence of landscape change and ecological variability from proximal, medial and distal settings within regional catchments is reconstructed.

Systematic survey and excavation conducted within Northern Oman during 2018/19 identified Early Holocene and Neolithic surface and stratified sites, including Hayy al-Sarh in Rustaq (Bretzke et al. 2018) and IB19 near Ibri (Fig. 1). Excavations at both sites, along with geoarchaeological and palaeoenvironmental analyses are ongoing, and will be successively reported in future publications.

\section{Rustaq}

\section{Regional Landscape and Palaeoenvironmental Setting}

The town of Rustaq is situated along the foothills of the Western Hajar Mountains, which are dominated by the Semail ophiolite nappe, and run in a parallel arc to the coast of the Gulf of Oman. Weathered material from the mountains is the predominant sediment source for much of the alluvial plain immediately north of the town, with rainfall across the mountain catchment activating the northeastwards flow of surface and subsurface drainage towards the coast. The town of Rustaq is situated within the proximal alluvial fan zone, where relict landforms indicate a substantially wetter 
120

121

122

123

126

128

130

131

132

133

134

135

136

137

138

139

140

141

142

143

144

climate than that of today. These occur as a series of small hills extending northeastwards from the mountain front and comprise coarse, poorly sorted, highly cemented polymict conglomerates. These earliest deposits have been altered by subsequent fan aggradation and channel flows, which are found either banked against the side of the older, larger fan system, or have incised through the relict fan lobe to leave terraces of stacked fan channel sediments immediately adjacent to the modern channel floor. The Neolithic site Hayy al-Sarh (Fig. 2) is located at the base one such channel ridge. Adjacent to these are a series of younger (likely Mid-Late Pleistocene) terraces upon which Neolithic material has been identified, and on which the Hayy alSarh site is located. These terraces were also observed within the proximal fan zone as stream flow and sheet-flood sediments. They are typically characterised by fining-up sequences and channelized beds of gravels and gravelly sand, underlain by a thick sequence of silt-sands. The fining-upwards of sediments from gravels to sand is indicative of the waning of alluviation, following a steady decrease in rainfall across the region.

Adjacent to the main channel, and approximately $3 \mathrm{~m}$ lower than the terrace on which Hayy al-Sarh is located, a small conglomerate terrace (HAS19) was identified (Fig.

3). Geomorphological investigation suggests that the terrace represents a phase of Holocene channel aggradation, based on relative position to both the main channel (i.e. the most recent 'wet phase') and that of the large Pleistocene terrace to the south. Given this, and the presence of the Neolithic site of Hayy al-Sarh, the small terrace section was logged in the field with samples extracted for optically stimulated luminescence (OSL) dating and palaeoenvironmental analyses. The sequence at HAS19 S1 comprises a ca. $4.5 \mathrm{~m}$ section of stratified fluvial gravels and palaeosols, 
145

146

147

148

149

150

151

152

153

154

155

156

157

158

159

160

161

162

163

164

165

166

167

168

during the Holocene period. Samples for luminescence dating were obtained from within the main palaeosol so that a chronology for hydrological changes during the Holocene can be developed. Given the paucity of terrestrial Holocene palaeoenvironmental records in Northern Oman, developing a record of hydrodynamics for the region for this time should be considered a high priority.

Further fieldwork will seek to expand upon the work conducted in the Rustaq region, and extend geomorphological investigations towards the medial and distal parts of the alluvial plain.

\section{Hayy al-Sarh: Preliminary Results}

Bretzke et al. (2018) have recently introduced the site and provide details on its archaeology as well as chronology, from which we summarize here. Excavations at the site recovered two archaeological horizons (AH I \& II). AH I contains artifacts indicating typical Arabian Neolithic bifacial reduction likely related to the Suwayh culture defined by Charpentier (2008). AH I also contained pierced marine shells probably of the species Polinices mammilla, which date the occupation between 7,500-7,000 years before present. AH II currently remains undated. Searching the surface adjacent to the excavation, the team observed potentially artificial accumulations of larger stones. Their function remained unclear, but the team decided to excavate them in the following season.

Fieldwork in 2019 revealed the multifunctional character of the site, which is likely composed of a settlement area and an area related to burial activities. Three of the previously observed surface stone structures were selected for excavation. While excavations could not securely identify a function of these structures, two of these 
169

170

171

172

173

174

175

176

177

178

180

181

182

183

184

185

186

187

188

189

190

191

192

stone features produced archaeological remains embedded in the excavated sediments

(Fig. 4). The majority of these come from excavation of a roundish accumulation of

bigger $(>20 \mathrm{~cm})$ stones located at the foot slope of the terrace forming the western end

of the site. Besides unspecific stone artefacts, these include a stone hemisphere,

pierced shells from two new species and animal remains (Fig. 4). All these finds fit

well with known assemblages from the $5^{\text {th }}$ to $6^{\text {th }}$ millennium BC. At a depth of about

$10 \mathrm{~cm}$ below surface, a second stone accumulation was recovered. This comprised a

roundish structure resembling a tomb (Fig. 4). Since this was discovered on the final

day of fieldwork, it was decided to protect this finding for future work by re-filling

the trench.

\section{Ibri}

\section{Regional Landscape and Palaeoenvironmental Setting}

The hydrology of the Ibri region is dominated by the Oman Mountains, which are composed of Mesozoic rocks of the Neotethys margin, Late Cretaceous-Paleogene thrust faults, Paleogene sediments and post-orogenic faults (Glennie et al., 1974;

Lippard et al., 1986; Searle and Cox, 1999; Rodgers and Gunatilaka, 2002).

Weathered material from the mountains is the dominant sediment source for much of

the geomorphology surrounding in the area, while rainfall across the mountain

catchment activates the flow of surface and subsurface drainage towards the Rub al

Khali and the Umm as Sammim. In order to construct a framework of climatically

driven landscape change for the region, initial field survey focused on a

geomorphological analysis of landforms extending southwest from the Ibri piedmont region in proximal and medial locations, and identifying and logging sedimentary 
193

194

195

deposits suitable for future palaeoenvironmental reconstruction and dating. Field survey during 2019 identified at least two distinct phases of alluvial fan and drainage activation in the Ibri region. The oldest evidence of alluvial fan drainage activation is found within the medial alluvial zone approximately $20 \mathrm{~km}$ from the mountain front, where relict landforms indicate a substantially wetter climate than that of today. These occur as a series of sinuous, low hills inverted relative to modern drainage, which extend southwestwards from the mountains and comprise coarse, poorly sorted, highly cemented polymict conglomerates. Within the proximal zone, an area of dark, indurated gravel terraces were identified ca. $500 \mathrm{~m}$ from the mountain front. These comprise stratified sequences of conglomerates and palaeosols that have been incised by more recent flow, and represent a more recent phase of drainage development than that observed within the medial zone. A ca. $7 \mathrm{~m}$ sequence (IB19 S1) (Fig. 3) adjacent to the Ibri Sports Ground was logged in the field, with block samples extracted for OSL dating.

The sequence at IB19 S1 represents the development of extensive grasslands and fluvial systems under much wetter conditions than those of today. The thick palaeosol units within the sequence represent generally well-developed aridisols that would likely have formed over several hundred, if not several thousand years. In addition, evidence of channelised flow indicates the extension of rivers from the mountain front. The sequence of landscape changes at the site, therefore, indicates the periodic extension of rivers within the Ibri region, followed by either a reduction in discharge or the avulsion of channels and the subsequent development of grasslands. The wider feature, of which IB19 S1 is just a part, was mapped with further exposures logged for possible future analyses. Future work will include investigations further south towards the Rub al Khali to establish the extent of channel flow, and also within the upper 
239 about $10_{2} 000$ years ago (Charpentier and Crassard, 2013). such, is considered a high priority, and particularly in light of the recent archaeological studies outlined in this report.

\section{Ibri Rock Shelter: Preliminary Results}

catchment/source area. The development of a chronology, combined with palaeoenvironmental data will represent the first such study from the region and as

In 2019 excavation commenced at a rock shelter site identified in 2018. This rock shelter is located around $8 \mathrm{~km}$ west of the centre of Ibri. The rock shelter is $6 \mathrm{~m}$ wide and $2.5 \mathrm{~m}$ deep, while sedimentary deposits in front of the rock shelter form a horizontal terrace under the present roof and a slope further outside (Fig. 5). Excavation was undertaken within a 3 by $1 \mathrm{~m}$ trench. In total 135 lithic artifacts from three AHs have been documented (Tab. 1). Besides lithic artifacts and naturally occurring terrestrial snails, no other find classes were found during this excavation. The upper most archaeological horizon (AH I) occurs between 4 and $10 \mathrm{~cm}$ below the modern surface. Angular debris, which always occurs during the knapping process, forms the majority of finds. Only six flakes larger than $2 \mathrm{~cm}$ were found. Since no specific tools occur, an age estimate based on the archaeology is not possible.

The next layer is between 20 and $30 \mathrm{~cm}$ thick and occurs at depths between 10 and 40 $\mathrm{cm}$ below present surface. It contains AH II with 55 lithic artefacts. Among them are one Fasad point (Fig. 5) and one small unidirectional flake core. The Fasad type point is well known in Oman and was produced by human groups living in southern Arabia 
240 A total of 13 lithic artefacts were recovered from the currently deepest layer, which

241 was named AH III. None of the artefacts from AH III feature characteristics that

242 allow it's assignation to any known period. However, given that this layer underlies

243 AH II, which can be placed into the eighth millennium BC, AH III likely represents a

244 phase of Pleistocene human occupation. This conclusion is supported by the

245 observation of patina on lithics from $\mathrm{AH}$ III. No other $\mathrm{AH}$ from our excavation

246 contains patinated artifacts. Four sediment samples for OSL dating of the exposed

247 archaeological stratigraphy were collected at the site and these results, along with

248 those of further excavations, will be reported in future publications.

\section{Summary Conclusions}

251 Results of the 2018/2019 field campaign by the PEARL project confirm the presence

252 of stratified archaeological material in the Ibri rock shelter and extend the spatial

253 distribution of stratified material at Hayy al-Sarh. Despite its explorative character,

254 the 2018/2019 fieldwork has led to some important observations. First, the presence

255 of a stratified Fasad assemblage at Ibri rock shelter is a rare find and provides an

256 exciting opportunity to study the Fasad lithic tradition in greater detail and contribute

257 to a better understanding of the chronology of this archaeological entity. Moreover,

258 given at least one underlying archaeological assemblage in addition to potential for

259 deeper excavations, Ibri rock shelter provides promising potential for contributing to

260 scientific debates about the Late Palaeolithic period and the transition to the Neolithic

261 about 8,000 to 10,000 years ago.

262 With its diverse archaeological record and finds such as animal remains, stone and

263 shell beads, and stone structures occurring in an area of at least 60 by $60 \mathrm{~m}$, the 
264 Neolithic site Hayy al-Sarh in Rustaq has very good potential for future research on

265 human settlement in inland regions and their contacts to coastal communities about

2667,000 years ago. The available radiocarbon dates clearly indicate that Hayy al-Sarh is

267 a Neolithic site with settlement and burial areas. Given that Neolithic tombs usually

268 occur not as single items but in often greater number, Hayy al-Sarh probably

269 compares with important Neolithic burial sites such as Ras al Hamra 5 (Marcucci, et

270 al., 2011) or Buhais 18 (Uerpmann, et al., 2000).

271 Alongside the archaeological sites excavated by the PEARL project, the identification

272 of excellent palaeoenvironmental sequences in close vicinity, indicate that continuing

273 work in these areas will provide important contributions for developing our

274 understanding of changing climatic and landscape conditions in the past and their

275 impact on humans in prehistory. Future fieldwork and analyses will increase

276 archaeological assemblages and palaeoenvironmental data to help build a framework

277 of cultural and natural developments in northern Oman.

278

279

280

281

282

283

284

285

\section{References}

Bretzke, K., Parton, A., Lindauer, S., Kennet, D. (2018). Evidence of Neolithic settlement in the foothills of the Western al-Hajar Mountains. Arabian Archaeology and Epigraphy 29, 103-114.

Charpentier, V. (2008). Hunter-gatherers of the "empty quarter of the early Holocene" to the last Neolithic societies: chronology of the late prehistory of south-eastern Arabia (8000-3100 BC), Proceedings of the Seminar for Arabian Studies 38 59-82. 
286 Charpentier, V. and Crassard, R. (2013). Back to Fasad... and the PPNB controversy. 287 Questioning a Levantine origin for Arabian Early Holocene projectile points 288 technology. Arabian Archaeology and Epigraphy, 24(1), pp.28-36.

289 Crassard, R. and Drechsler, P. (2013). Towards new paradigms: multiple pathways for 290 the Arabian Neolithic. Arabian Archaeology and Epigraphy, 24(1), pp.3-8.

291 Drechsler, P. (2010). Life at the end of the Holocene moist phase in south-east Arabia 292 - the Late Neolithic site of Jebel Thanais 1 (JTH1). Arabian Archaeology and 293 Epigraphy 21, 81-95.

294 Feulner, G.R. (1998). Wadi fish of the UAE. Tribulus, 8(2), pp.16-22.

295 Fleitmann, D., Burns, S.J., Mangini, A., Mudelsee, M., Kramers, J., Villa, I., Neff, U., 296 Al-Subbary, A.A., Buettner, A., Hippler, D. and Matter, A. (2007). Holocene ITCZ 297 and Indian monsoon dynamics recorded in stalagmites from Oman and Yemen 298 (Socotra). Quaternary Science Reviews, 26(1-2), pp.170-188.

299 Glennie, K.W., Boeuf, M.G.A., Hughes Clarke, M.W., Moody-Stuart, M., Pilaar, 300 W.F.H., Reinhardt, B.M. (1974). Geology of the Oman Mountains. Royal Dutch 301 Geological and Mining Society, The Hague.

302 Kallweit, H., Beech, M., al-Tikriti, W.Y. (2005). Kharimat Khor al-Manāhil and Khor 303 Āl Manāhīl — New Neolithic sites in the south-eastern desert of the UAE 304 Proceedings of the Seminar for Arabian Studies 35, 97-113.

305 Kwarteng, A.Y., Dorvlo, A.S. and Vijaya Kumar, G.T. (2009). Analysis of a 27-year 306 rainfall data (1977-2003) in the Sultanate of Oman. International Journal of 307 Climatology, 29(4), pp.605-617. 
308 Lemée, M., Gernez, G., Giraud, J., Beuzen-Waller, T., Fouache, É. (2013). Jabal al309 Aluya: an inland Neolithic settlement of the late fifth millennium BC in the Ādam 310 area, Sultanate of Oman. Proceedings of the Seminar for Arabian Studies 43, 197-212.

311 Lézine, A.M., Robert, C., Cleuziou, S., Inizan, M.L., Braemer, F., Saliège, J.F., 312 Sylvestre, F., Tiercelin, J.J., Crassard, R., Méry, S. and Charpentier, V. (2010).

313 Climate change and human occupation in the Southern Arabian lowlands during the 314 last deglaciation and the Holocene. Global and Planetary Change, 72(4), pp.412-428.

315 Lippard, S., Shelton, A., Gass, I. (1986). The Ophiolite of Northern Oman. Blackwell 316 Scientific Publications, Oxford.

317 Marcucci, L.G., Genchi, F., Badel, E. and Tosi, M. (2011). Recent investigations at 318 the prehistoric site RH-5 (Ra's al-Hamra, Muscat, Sultanate of Oman). In Proceedings 319 of the Seminar for Arabian Studies (Vol. 41, pp. 201-222).

320 Parker, A.G., Goudie, A.S., Stokes, S., White, K., Hodson, M.J., Manning, M., 321 Kennet, D. (2006). A record of Holocene climate change from lake geochemical 322 analyses in south-eastern Arabia. Quat. Res. 66, 465-476.

323 Patzelt, A., Harrison, T., Knees, S.G. and Al Harthy, L. (2014). Studies in the flora of 324 arabia: xxxi. new records from the sultanate of oman. Edinburgh Journal of 325 Botany, 71(2), pp.161-180.

326 Preston, G.W., Thomas, D.S., Goudie, A.S., Atkinson, O.A., Leng, M.J., Hodson, 327 M.J., Walkington, H., Charpentier, V., Méry, S., Borgi, F. and Parker, A.G. (2015). A 328 multi-proxy analysis of the Holocene humid phase from the United Arab Emirates and 329 its implications for southeast Arabia's Neolithic populations. Quaternary 330 International, 382, pp.277-292. 
331 Rodgers, D.W., Gunatilaka, A. (2002). Bajada formation by monsoonal erosion of a 332 subaerial forebulge, Sultanate of Oman. Sedimentary Geology 154127 - 146.

333 Rose, J.I., Usik, V.I., Angelucci, D.E., Al-Mahrooqi, A. (2014). A Stratified

334 Early/Middle Holocene Site inside the Qārat al-Kibrīt Dome. The Journal of Oman 335 Studies 17, 51-71.

336 Searle, M., Cox, J. (1999). Tectonic setting, origin, and obduction of the Oman 337 ophiolite. Geological Society of America Bulletin, 104-122.

338 Sherif, M., Almulla, M., Shetty, A. and Chowdhury, R.K. (2014). Analysis of rainfall, 339 PMP and drought in the United Arab Emirates. International journal of 340 climatology, 34(4), pp.1318-1328.

341 Uerpmann, M. and Uerpmann, H.-P. (2000). Faunal Remains of Al-Buhais 18. An 342 aceramic neolithic site in the Emirate of Sharjah (SE-Arabia)- Excavations 1995343 1998. In M. Mashkour, A.M. Choyke, H. Buitenhuis and F. Poplin eds.

344 Archaeozoology of the Near East IVB. Proceedings of the fourth international 345 symposium on the archaozoology of southwestern Asia and adjacent areas. 346 Groningen, pp. 40-49. ARC Publicaties.

347 Uerpmann, H.P., Uerpmann, M., Kutterer, A. and Jasim, S.A. (2013). The Neolithic 348 period in the Central Region of the Emirate of Sharjah (UAE). Arabian Archaeology 349 and Epigraphy, 24(1), pp.102-108.

350 Uerpmann, M., Uerpmann, H.P., Hinderer, M., Lindauer, S., Neureiter, C., 351 Ghukasyan, R., Kesejyan, S. and Petrosyan, A. (2018). HLO 1-south: An Early 352 Neolithic site in Wadi al-Hilo (Sharjah, UAE). Arabian Archaeology and 353 Epigraphy, 29(1), pp.1-9. 
$\underline{\text { Title: }}$

The PalaeoEnvironments and ARchaeological Landscapes (PEARL)

project: recent findings from Neolithic sites in Northern Oman

Running title:

Neolithic settlement and landscapes of Northern Oman

Authors:

Ash Parton ${ }^{1,2}$, Knut Bretzke ${ }^{3}$,

1- Human Origins and Palaeoenvironments Research Group, Department of Social Sciences, Oxford Brookes University, UK

2- Mansfield College, University of Oxford, UK

3- University of Tübingen, Dept. Early Prehistory and Quaternary Ecology, Schloss Hohentübingen, D-72070 Tübingen, Germany

\section{Conflict of Interest statement:}

The authors have no conflict of interest to declare.

Acknowledgements:

We thank the Oman Ministry of Heritage and Culture for kind permission to conduct field work in the regions of Rustaq and Ibri. The Anglo-Omani Society in London generously funded the RBAS project. KB wishes to thank the research project "The role of culture in early expansions of humans" of the Heidelberg Academy of Science and Humanities for a travel grant and the Gerda Henkel Stiftung (AZ 06/V/18) for financial support of research in Oman. AP wishes to thank the RGS Thesiger-Oman Fellowship for financial support with continuing fieldwork as part of the PEARL project, and Sam Woor for his assistance in the field. 


\section{Tables}

Table 1. Overview of archaeological finds from the excavation at rock shelter site IB19. Chips $=$ flakes $<2 \mathrm{~cm}, \mathrm{AD}=$ angular debris.

\begin{tabular}{|c|c|c|c|c|c|c|c|c|c|}
\hline GH & AH & $\begin{array}{c}\text { total } \\
\text { artifacts }\end{array}$ & cores & Tools & flakes & chips & AD & artifacts/m $\mathbf{m}^{2}$ & comment \\
\hline 1 & I & 55 & 0 & 0 & 6 & 16 & 33 & 18.3 & \\
$1 . a$ & II & 57 & 1 & 1 & 9 & 17 & 29 & 19.0 & Fasad point \\
2 & III & 13 & 0 & 0 & 5 & 0 & 8 & 4.3 & patinated flakes \\
\hline
\end{tabular}




\section{Figure Legends}

2 Figure 1. Location of the Rustaq and Ibri study regions (a) within wider regional

3 setting (inset), Rustaq study area showing location of Hayy al-Sarh site and HAS19

4 S1 palaeoenvironmental sequence (b), and Ibri study area showing locations of the

5 rock shelter site and IB19 S1 palaeoenvironmental sequence (c).

6 Figure 2. Overview of site Hayy al-Sarh (drone photo), showing location of features

7 outlined in Figure 4.

8 Figure 3. Photos showing palaeoenvironmental sequences comprising stratified

9 gravels and well developed palaeosols adjacent to both the sites: a ca. $4.5 \mathrm{~m}$ section 10 (HAS19 S1) near Hayy al-Sarh (a), and a ca. $7 \mathrm{~m}$ section (IB19 S1) near the Ibri rock

11 shelter site (b).

12 Figure 4. Overview of area excavated in 2019. Circles indicate excavated features.

13 While Feature 1 (right circle) did not contain archaeological remains, pierced marine

14 shells have been found at Feature 3 (middle) and Feature 4 (left). Excavations of

15 Feature 4 also produced animal remains and a stone hemisphere (upper left corner), as

16 well as a roundish stone package resembling a tomb (lower left corner).

17 Figure 5. Rock shelter site IB19. A) Overview (view to west). B) Orientation of

18 excavated trench. C) Fasad type point found in AH II. D) Drawing of the eastern

19 profile at $\mathrm{x}=61 \mathrm{~m}$ showing the vertical distribution of archaeological horizons (AHs)

20 and geological horizons (GHs) as well as the location of OSL samples collected from

21 this profile. 


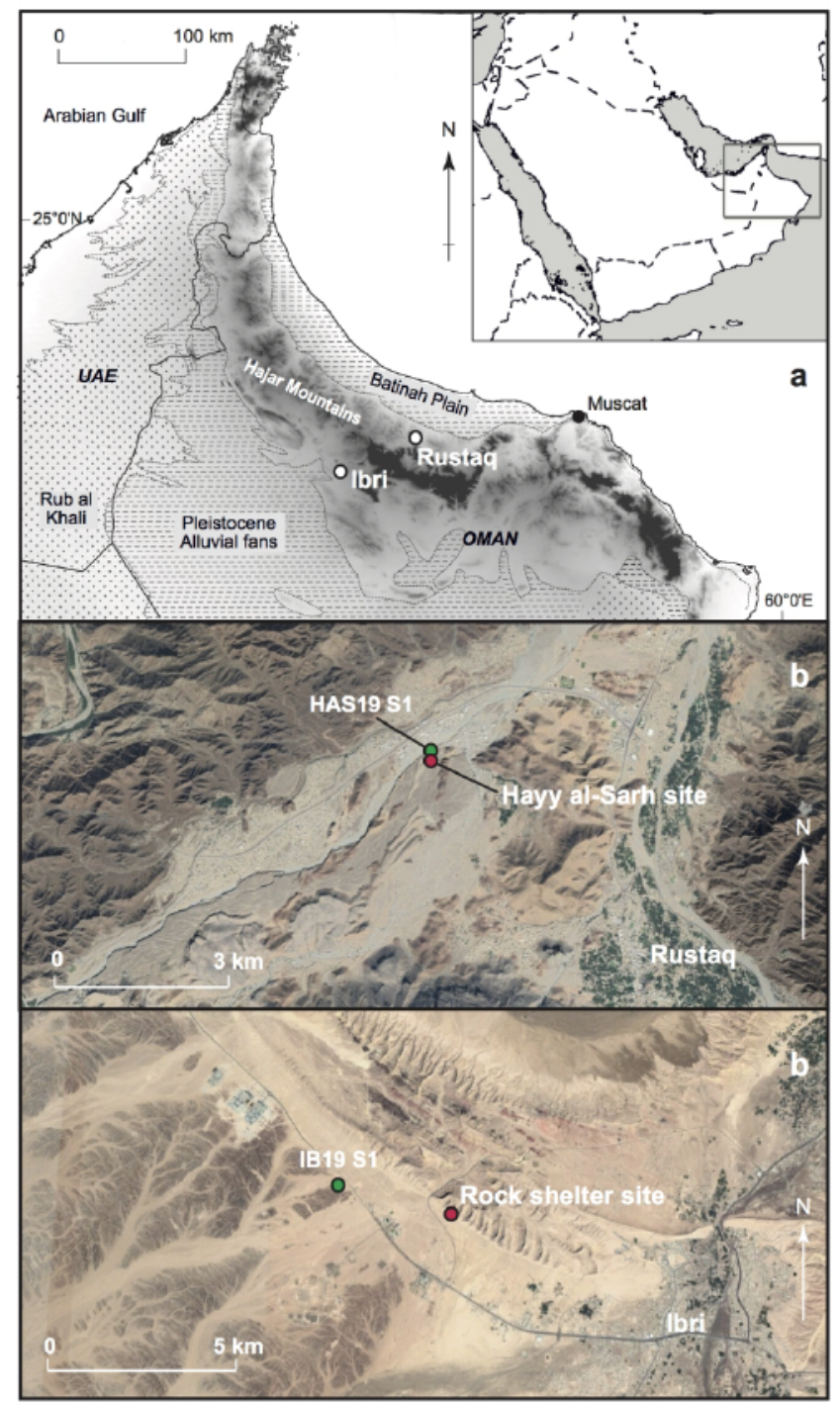

Figure 1. Location of the Rustaq and Ibri study regions (a) within wider regional setting (inset), Rustaq study area showing location of Hayy al-Sarh site and HAS19 S1 palaeoenvironmental sequence (b), and Ibri study area showing locations of the rock shelter site and IB19 S1 palaeoenvironmental sequence (c). 
Figure 2. Overview of site Hayy al-Sarh (drone photo), showing location of features outlined in Figure 4. $296 \times 209 \mathrm{~mm}(200 \times 200$ DPI $)$ 
Figure 3. Photos showing palaeoenvironmental sequences comprising stratified gravels and well developed palaeosols adjacent to both the sites: a ca. $4.5 \mathrm{~m}$ section (HAS19 S1) near Hayy al-Sarh (a), and a ca. $7 \mathrm{~m}$ section (IB19 S1) near the Ibri rock shelter site (b). 


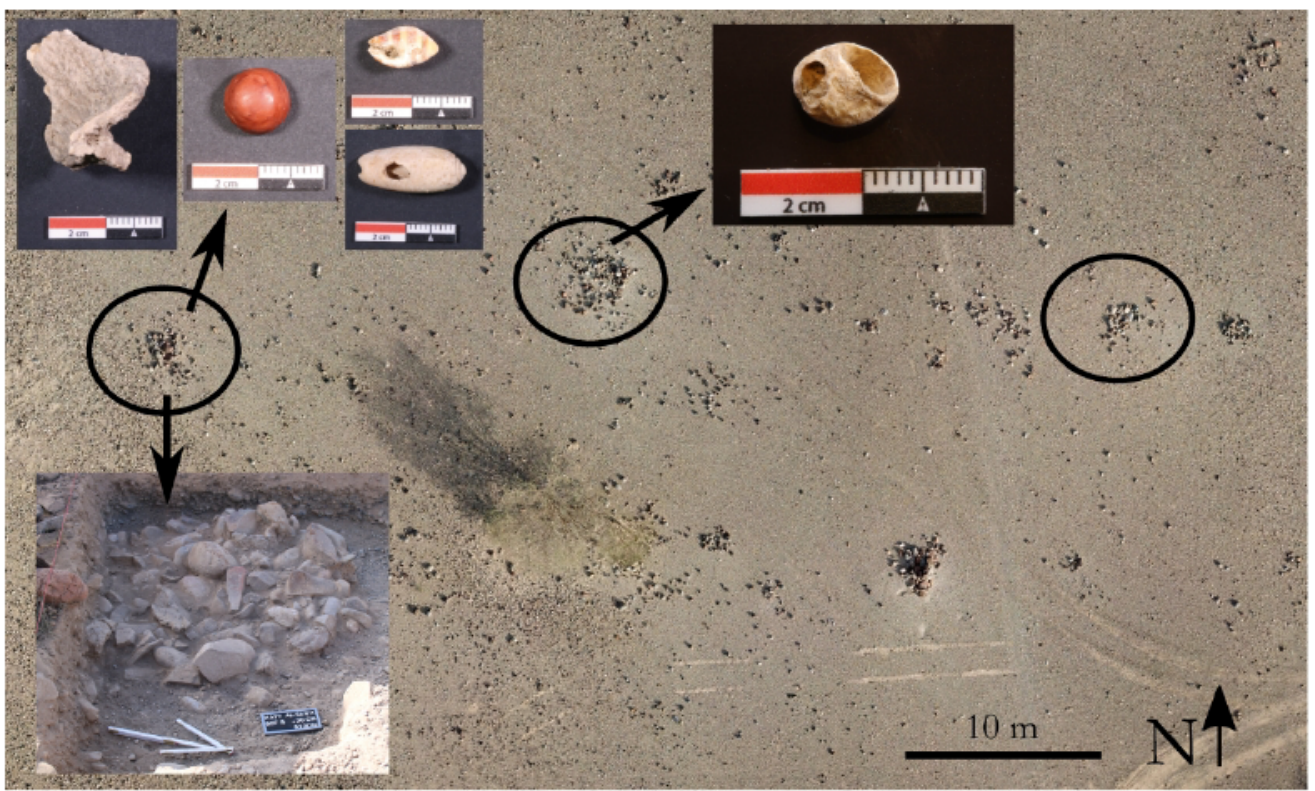

Figure 4. Overview of area excavated in 2019. Circles indicate excavated features. While Feature 1 (right circle) did not contain archaeological remains, pierced marine shells have been found at Feature 3 (middle) and Feature 4 (left). Excavations of Feature 4 also produced animal remains and a stone hemisphere (upper left corner), as well as a roundish stone package resembling a tomb (lower left corner). 

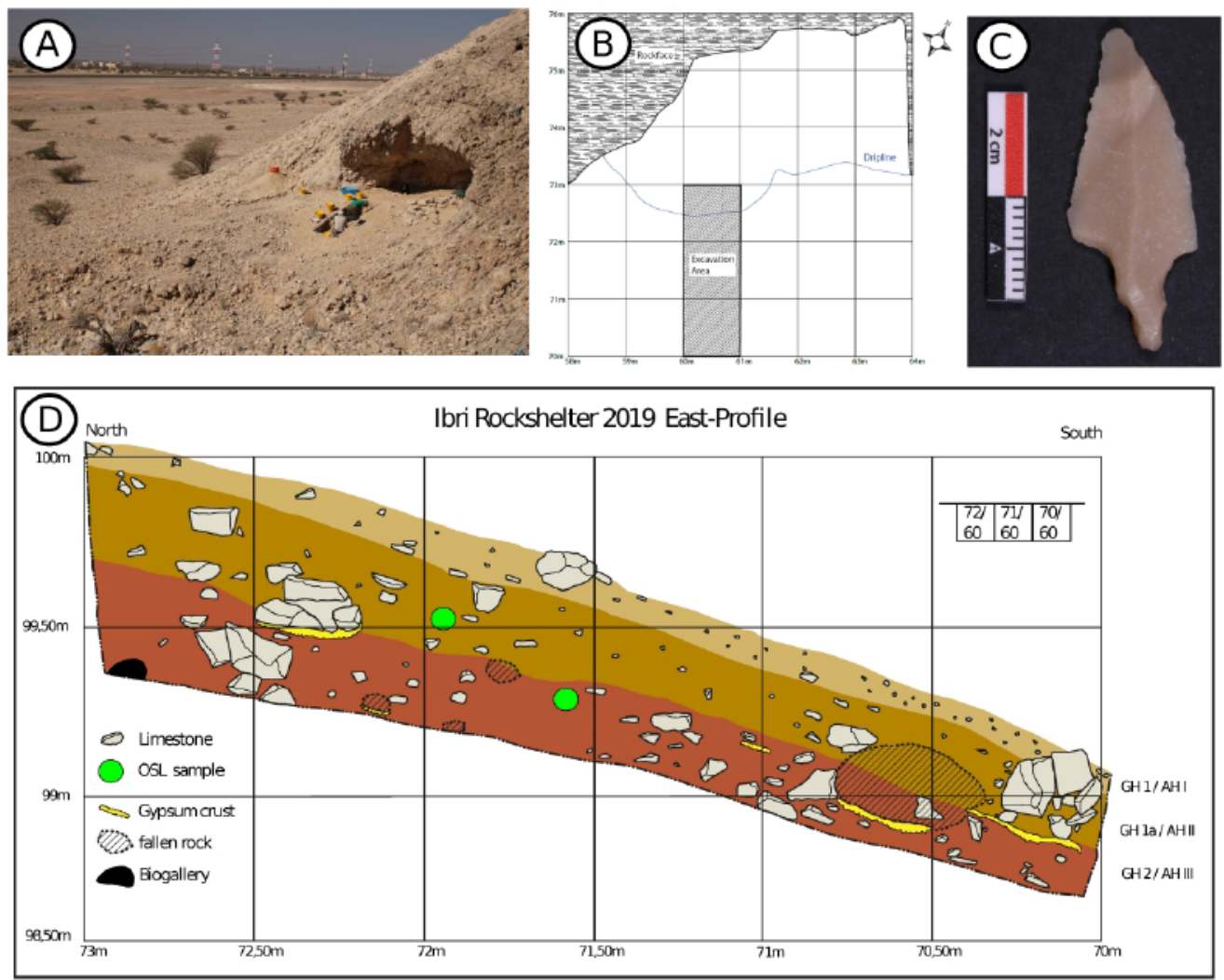

Figure 5. Rock shelter site IB19. A) Overview (view to west). B) Orientation of excavated trench. C) Fasad type point found in AH II. D) Drawing of the eastern profile at $x=61 \mathrm{~m}$ showing the vertical distribution of archaeological horizons (AHs) and geological horizons (GHs) as well as the location of OSL samples collected from this profile.

$362 \times 290 \mathrm{~mm}(300 \times 300 \mathrm{DPI})$ 